International Journal of Engineering \& Technology, $7(3.12)(2018) 137-139$
International Journal of Engineering \& Technology
SPC
Website: $w$ ww.sciencepubco.com/index.php/IJET
Research paper

\title{
Geometric Design of Highways for Accommodation of More Traffic Volume with Increased Design Speed
}

\author{
S Srikiran ${ }^{1}$, S Deepak Kumar ${ }^{2 *}$ C Venkatasubramanian ${ }^{3}$, D Muthu ${ }^{4}$, S Suriyanarayanan ${ }^{5}$ \\ 1,2,3,4,5 School of Civil Engineering, SASTRA Deemed University, Thanjavur, Tamil Nadu, India \\ *Corresponding Author Email: ${ }^{1}$ kiran26897@gmail.com, ${ }^{2 *}$ deeps.11001@gmail.com \\ ${ }^{3}$ cv@civil.sastra.edu, ${ }^{4}$ dmuthu@civil.sastra.edu, ${ }^{5}$ suriyanarayanan@civil.sastra.edu
}

\begin{abstract}
Road transport plays an important role in India's economy. It enables the country's transportation sector to contribute $6.1 \%$ towards India's GDP. The road network in our country is considered as a critical factor to the country's development, social integration and security needs of the country. The Government of India has promoted foreign investments in highway projects to bring out high standards and quality. India's road network carries over $65 \%$ of freight and $85 \%$ passenger traffic. The traffic volume carried by the national highways almost exceeds the designed traffic volume, and hence the desired speed cannot be achieved. Thus, widening of highways becomes necessary. The population growth is also to be considered and hence provision for future widening is to be provided. Our paper deal with the geometric design for widening of NH-9 is carried out using MX-Bentley software as per IRC specifications. This design includes horizontal and vertical profiling throughout the stretch of the road, according to the existing topographic data. The radius of the curve has been increased to make a smooth curve. Also, the vertical profile has been designed based on the allowable gradient and sight distances. From this, accommodation of more traffic volume and increment of design speed seems to be possible.
\end{abstract}

\section{Introduction}

NH-9 is a major highway that passes through the states of
Maharashtra (336 Km), Karnataka (75 Km) and Andhra Pradesh $(430 \mathrm{Km})$. The highway originates from Pune in Maharashtra and ends at Machilipatnam in Andhra Pradesh with a total length of $841 \mathrm{Km}$.

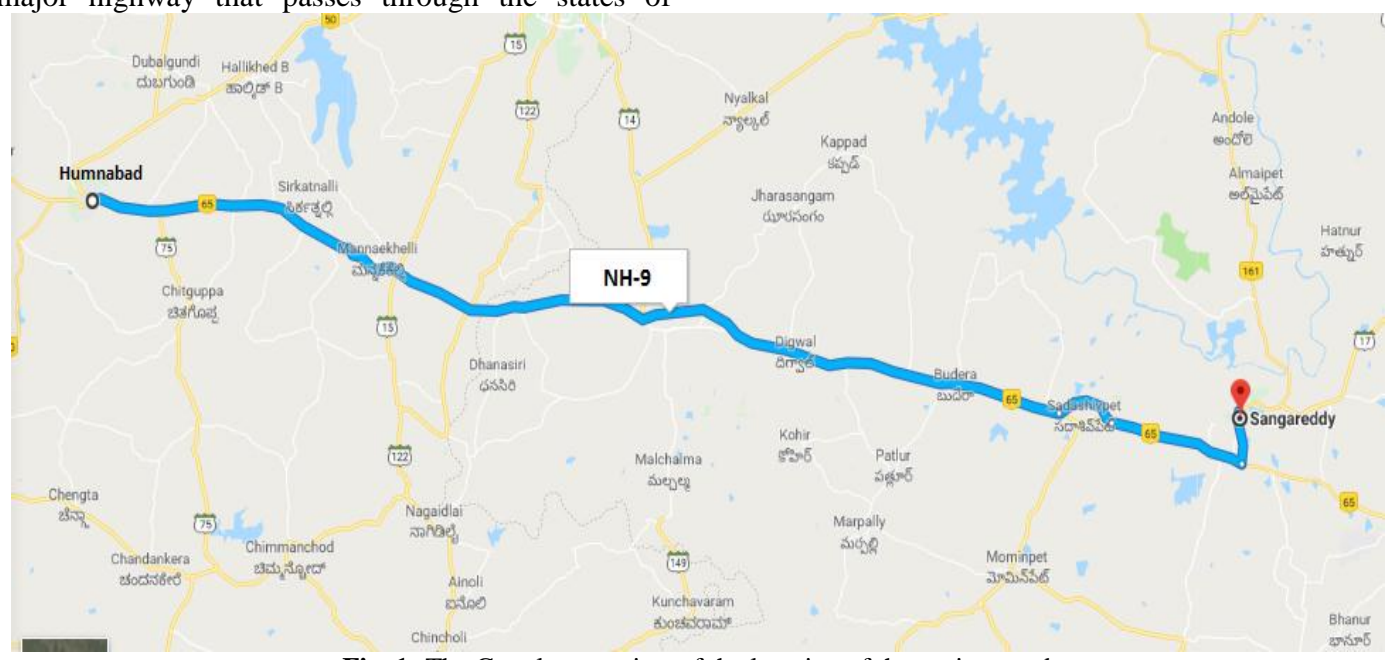

Fig. 1: The Google map view of the location of the project road

The project road is a section of NH-9 between MH/KA border $(\mathrm{Km}$ 348/800) and Sangareddy(Km 493/000) with a total length of $144.2 \mathrm{Km}$. The project road mainly passes through agricultural and barren land. It is a two lane undivided carriageway with paved shoulders on both sides.

The road passes through major places such as Humnabad, Zaheerabad and Sadasivapet. It provides connectivity to important places like Gangapur, Akkalkot, Tuljapur and Gulbarga. In our project a road length of $10 \mathrm{Km}$ of NH-9 (Humnabad to Sangareddy section) from $\mathrm{Km} 448 / 0$ to $\mathrm{Km} 458 / 0$ has been studied, analyzed and also the geometric design as per four lane standards using MX Bentley software has been carried out ${ }^{[1][2]}$.

\section{Objectives}

The main objectives of this presentation are

- To carry out the geometric design of $10 \mathrm{Km}$ stretch of NH-9 (Humnabad to Sangareddy section) from two lane to for lane as per IRC specifications. 
- To design the alignment of proposed center line based on the existing topographic features, economic aspects and obligatory points.

- To improve the existing substandard horizontal curves by increasing radius of curvature to four lane standards.

- To design the vertical profile in accordance with the sight distance, gradients, drainage and economical aspects.

- To design alignment plan based on typical cross section

- To generate the alignment plan, longitudinal section, detailed cross section (at $100 \mathrm{~m}$ interval), horizontal curve details for 10 $\mathrm{Km}$ length of highway.

\section{Technologies Used}

\section{Geometric Design}

\section{Design Standards Adopted}

Bentley MXROAD is an advanced, string based modeling tool that enables the rapid and accurate design of all road types. MXROAD automates much of the design and detailing process, saving the user time and money. MXROAD uses 3-D string modeling technology which is a concise method of creating any 3-D surface and digital terrain modeling for the ease of the users and removes manual errors.

Digital Terrain Model (DTM) creation and analysis, full alignment, road and junction design capability, 2-D and 3-D drainage design, volume and quantity extraction, integration with Google Earth and automated production of contract drawings complete a tool set.

Table 1: Design standards adopted in the presentation ${ }^{[3}$

\begin{tabular}{|c|c|c|}
\hline S. No & Items & Standards \\
\hline 1 & Design speed & $100 \mathrm{Kmph}$ \\
\hline 2 & Cross sectional requirements(urban/rural) & \\
\hline I) & Rural sections & \\
\hline a) & ROW & $60 \mathrm{~m}$ \\
\hline b) & $\begin{array}{c}\text { Minimum width of median } \\
\text { Raised median with mountable kerb ( IRC: } 86-1983 \text { ) }\end{array}$ & $4.5 \mathrm{~m}$ \\
\hline c) & $\begin{array}{l}\text { Width of carriageway on both sides of median } \\
\text { 2-lane carriageway with each lane of } 3.5 \mathrm{~m} \text { width }\end{array}$ & $7.0 \mathrm{~m}$ \\
\hline e) & Paved shoulder width & $1.5 \mathrm{~m}$ \\
\hline f) & Earthen shoulder width & $2.0 \mathrm{~m}$ \\
\hline II) & Urban sections & \\
\hline a) & ROW & $45 \mathrm{~m}$ \\
\hline b) & $\begin{array}{c}\text { Minimum width of median } \\
\text { Raised median with mountable kerb (IRC: } 86-1983 \text { ) }\end{array}$ & $2.0 \mathrm{~m}$ \\
\hline c) & $\begin{array}{l}\text { Width of carriageway on both sides of median } \\
\text { 2-lane carriageway with each lane of } 3.5 \mathrm{~m} \text { width }\end{array}$ & $7.0 \mathrm{~m}$ \\
\hline e) & Paved shoulder width & $2.0 \mathrm{~m}$ \\
\hline f) & Earthen shoulder width & - \\
\hline 3 & Horizontal Radius of curvature & \\
\hline a) & Desirable minimum radius requiring no super elevation & $2000 \mathrm{~m}$ \\
\hline b) & Desirable minimum radius requiring super elevation & $400 \mathrm{~m}$ \\
\hline 4 & Camber/ Cross fall & \\
\hline a) & Carriageway including paved shoulders & $2.5 \%$ \\
\hline b) & Earthen shoulders & $3.0 \%$ \\
\hline 5 & Super elevation & \\
\hline a) & Desirable & $5.0 \%$ \\
\hline b) & Maximum & $7.0 \%$ \\
\hline 6 & Stopping Sight Distance & \\
\hline a) & Desirable & $360 \mathrm{~m}$ \\
\hline b) & Minimum & $180 \mathrm{~m}$ \\
\hline 7 & Vertical alignment & \\
\hline a) & $\begin{array}{c}\text { Desirable distance between change in grade } \\
\text { (tangent points) }\end{array}$ & $150 \mathrm{~m}$ \\
\hline 8 & Gradient & \\
\hline a) & Maximum & $3.3 \%$ \\
\hline b) & Minimum & $0.3 \%$ \\
\hline
\end{tabular}

\section{Geometric Design Using Mx road Software Data required}

- Topography

- Topographic drawing

\section{Input Program Files}

- Ground- To create ground

- Carriageway- To specify carriageway width, shoulder width curve details, super elevation, earthwork
- Longitudinal section- To generate the vertical profile of the ground and the finished road level

\section{Design procedure}

- Importing ground data ${ }^{[8] ~}{ }^{[10]}$ : Topographic data (latitude, longitude and elevation) of various significant points are imported. Significant points include center line, carriageway edge, paved shoulder edge, earthen shoulder edge, structures and obligatory points. 


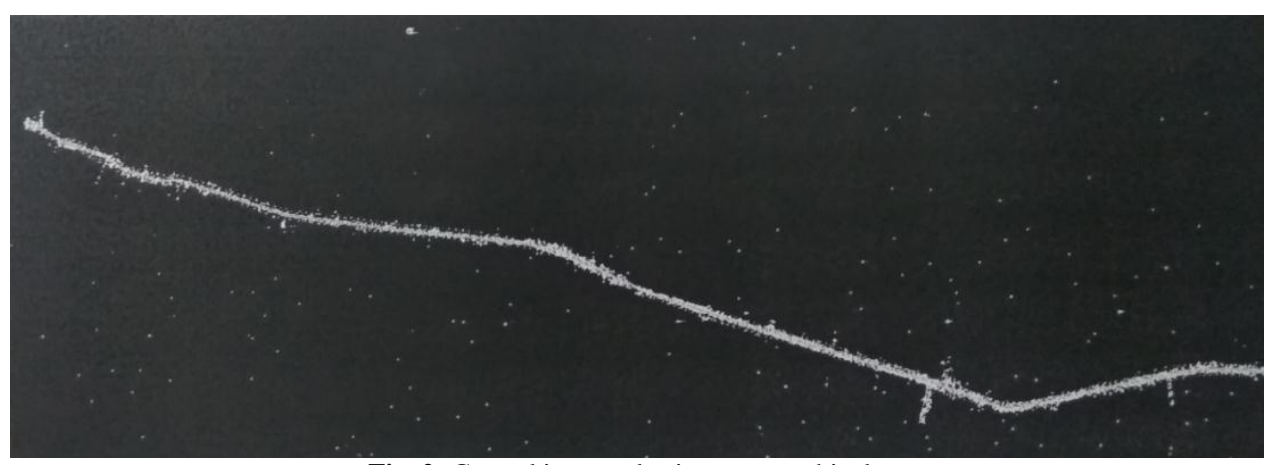

Fig. 2: Ground imported using topographic data

- Importing existing road drawing: The road lines from the existing topographic CAD drawing is imported along with the levels. The lines include center line, carriageway edge line, paved shoulder edge line and earthen shoulder edge line. It is then merged with the ground.

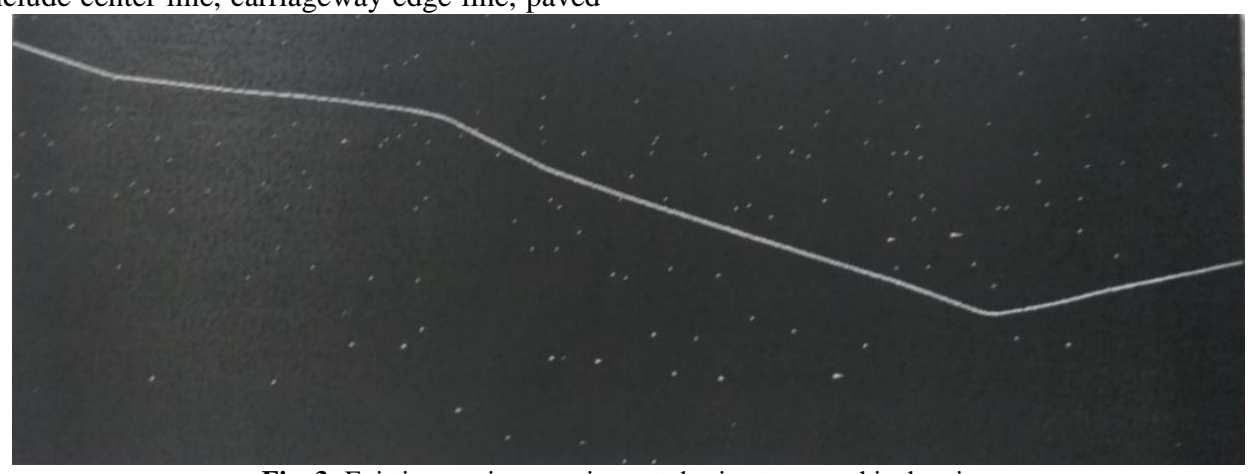

Fig. 3: Existing carriageway imported using topographic drawing

- Creating boundary: A boundary is created all around the existing road. The boundary should not be less than the Right of Way.

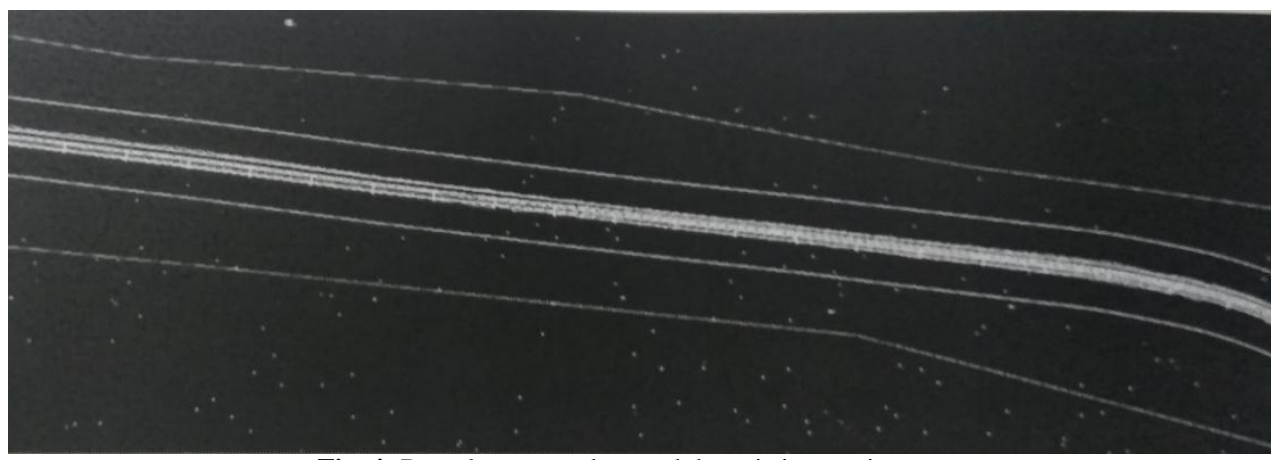

Fig. 4: Boundary created around the existing carriageway

- Triangulation: All points within the boundary are triangulated

to obtain the approximate levels. This is based on the Digital

Terrain Modeling.

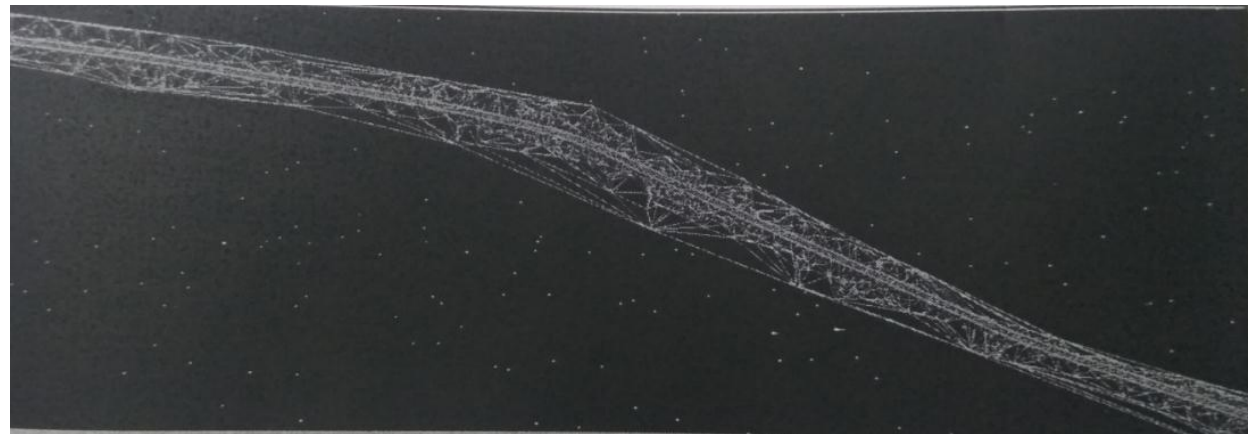

Fig. 5: Triangulation of all points within boundary

- Design: There are 3 parts in geometric design of highway ${ }^{[6][7][10]}$

a) Horizontal alignment

b) Vertical profiling

c) Detailed cross section

\section{a) Horizontal alignment}

i. Alignment shall be fluent and blend well with the surrounding topography. 
ii. All horizontal curves requiring super elevation shall consist of circular portion flanked by spiral transitions at both ends.

iii. Reverse curves maybe needed in difficult terrain. Sufficient length between two curves shall be provided for introduction of transition curves and super elevation.

iv. The curves in the same direction separated by short tangents known as broken Minimum length of transition curves shall be as per IRC: $73-1980^{[9]}$ for the specified design speed.

v. Back curves should be avoided.

vi. Radius of horizontal curves for various terrain conditions shall not be less than ruling minimum values as per IRC: 73$1980^{[9]}$ for the National Highways.

\section{b) Vertical profile}

i. Gradients up to the value corresponding to ruling gradient shall be provided.

ii. Grade changes shall not be too frequent as to cause kinks and visual discontinuities in the profile. Desirably there should be no change in grade within the distance of $150 \mathrm{~m}$.

iii. The curves in the same direction separatedby short tangents known as broken back curves should be avoided. iv. The aspect of efficient drainage shall be taken into consideration while designing vertical profile and cross sections of the highway.

v. The minimum gradient of $0.3 \%$ shall be provided in sections with kerbed edges.

vi. There shall be co-ordination between horizontal alignment and vertical profile of the project highway and guidelines in accordance with IRC: $73^{[9]}$.

\section{c) Detailed cross section}

i. Based on the design of horizontal alignment and vertical profiling, detailed cross sectional drawings are generated at regular intervals of $100 \mathrm{~m}$ for a stretch of $10 \mathrm{Km}$.

ii. This design is carried out as per IRC specifications for a 4-lane road in urban as well as rural areas.

iii. These drawings display the difference between existing ground and finished road.

iv. These drawings also provide information on median width, width of carriageway, width of paved shoulder, width of earthen shoulder, the respective cambers and slope provided for drainage

\section{Typical Cross Section Adopted}

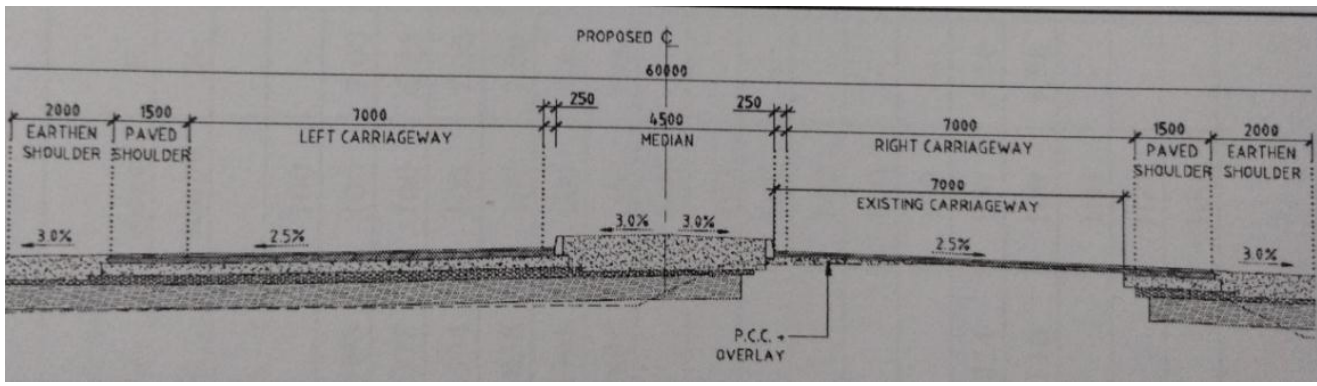

Fig. 6: Typical cross section-1

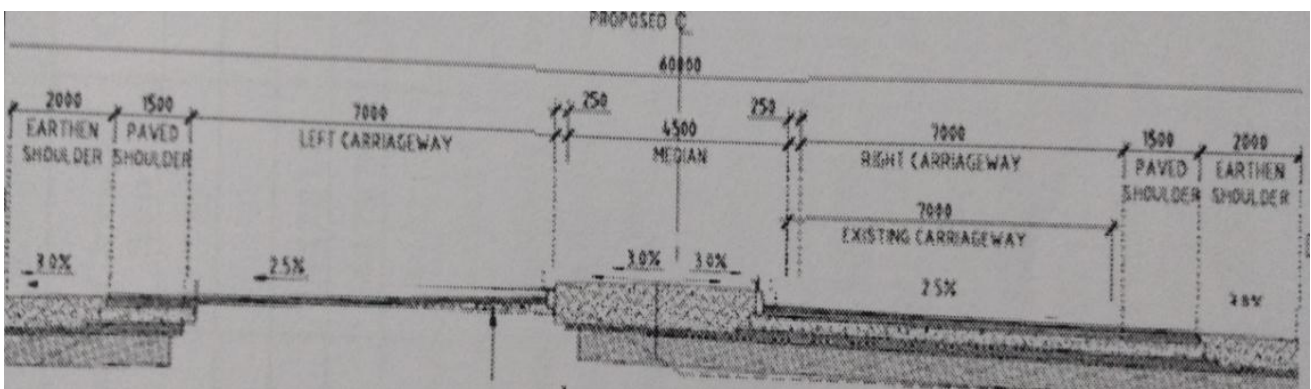

Fig. 7: Typical cross section-2

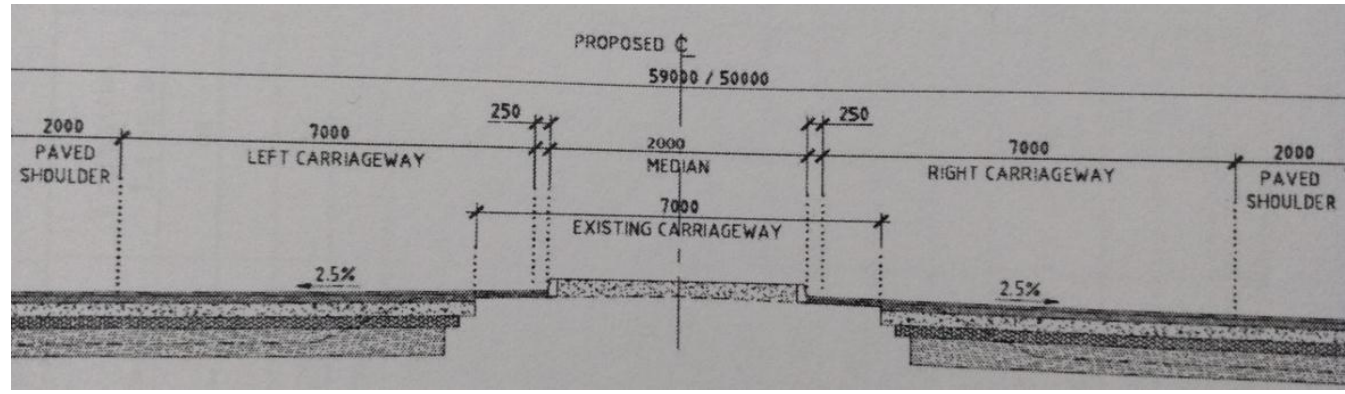

Fig. 8: Typical cross section-3

\section{Summary}

A $10 \mathrm{Km}$ stretch of a National Highway has been analyzed from NH-9 (Humnabad to Sangareddy) and the geometric design for the widening of road from 2-lane to 4-lane has been carried out using MX Bentley software based on IRC recommendations. The geometric design includes horizontal alignment, vertical profiling and designing the typical cross section for the above mentioned stretch of the highway.

\section{Conclusions}

- Geometric design for the widening of road from 2-lane to 4lane has been carried out using MX Bentley software based on IRC codes.

- Proposed centerline was designed based on existing topographic features, environmental issues, economic aspects and obligatory points. 
- Horizontal substandard curves were imported by increasing the radius and reducing the super elevation.

- Desirable speed (100Kmph) has been achieved for the entire $10 \mathrm{Km}$ stretch.

- Vertical profile was designed in accordance with the gradient and sight distances for achieving maximum speed.

\section{References}

[1] Khanna.S.K and Justo, C.E.J, Nemchand \& Bros, Highway Engineering, 1991, $7^{\text {th }}$ edition.

[2] L.R.Kadiyali, Khanna Publications, Traffic Engineering and Transport Planning, New Delhi, 2000, $5^{\text {th }}$ edition.

[3] Design Basis Report- MH/KA BORDER- SANGAREDDY ROAD PROJECT L\&T Infrastructure Development Project Ltd.

[4] Pavement design report- MH/KA BORDER- SANGAREDDY ROAD PROJECT L\&T Infrastructure Development Project Ltd.

[5] Report on Traffic Analysis \& Forecast- MH/KA BORDER SANGAREDDY ROAD PROJECT- L\&T Infrastructure Development Project Ltd.

[6] IRC SP-19-2001, "Manual for survey, investigation and preparation of road projects", Indian Road Congress, New Delhi.

[7] IRC 38-1988, Indian Road Congress, New Delhi.

[8] IRC SP-84-2009, "Geometric design standards for rural highways", Indian Road Congress, New Delhi.

[9] IRC 73-1980, "Manual for four laning of highways", Indian Road Congress, New Delhi.

[10] http://www.civilengineering.blogspot.com, importance of highways 